\title{
CORROSION CONTROL OF \\ CARBON STEEL RADIOACTIVE-LIQUID STORAGE TANKS
}

Topical Report

By

Ji Young Chang

May 1997

Work Performed Under Contract No. AC24-81NE44139

Prepared for

U.S. Department of Energy

Assistant Secretary for Nuclear Energy

Prepared by

West Valley Nuclear Services Company, Inc.

West Valley, NY 14171-0191

DISTRIBUTION OF THIS DOCUMENT IS UNLIMITED 


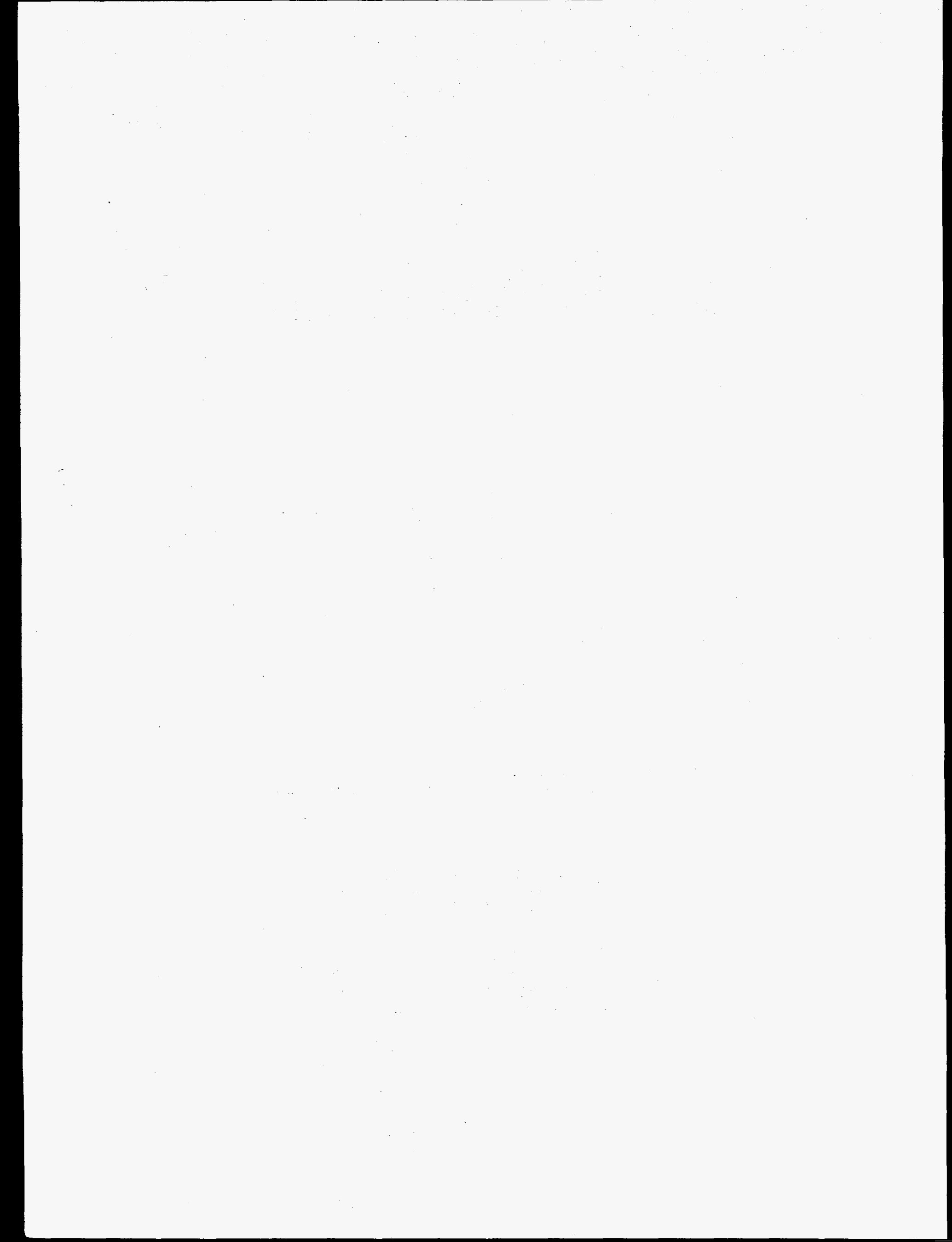




\section{DISCLAMMIER}

Portions of this document may be illegible in electronic image products. Images are produced from the best available original document. 


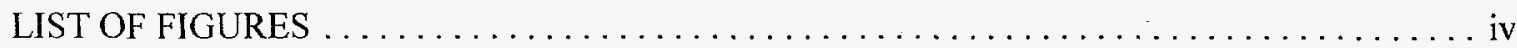

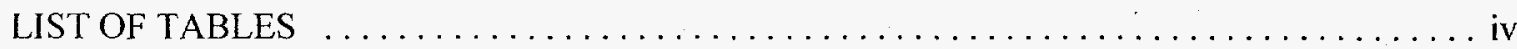

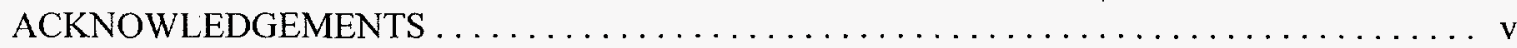

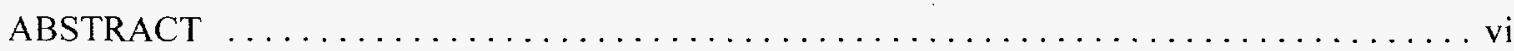

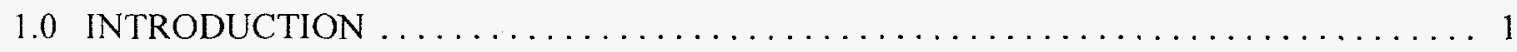

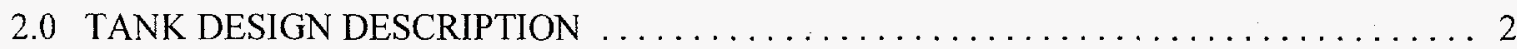

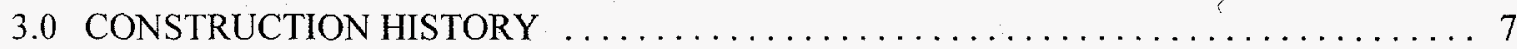

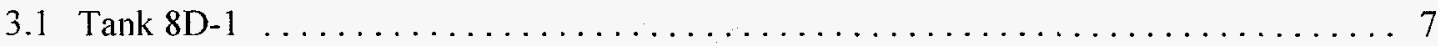

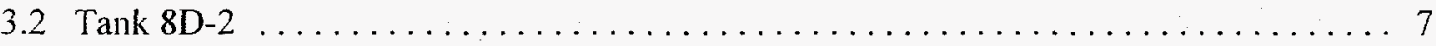

4.0 CORROSION ENVIRONMENT $\ldots \ldots \ldots \ldots \ldots \ldots \ldots \ldots \ldots \ldots \ldots \ldots \ldots \ldots \ldots \ldots$

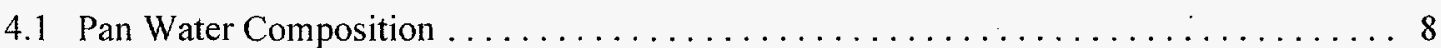

4.2 Temperature of Tank Wall and Pan Water $\ldots \ldots \ldots \ldots \ldots \ldots \ldots \ldots \ldots \ldots \ldots \ldots \ldots$

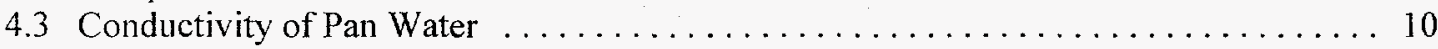

5.0 CORROSION OF CARBON STEEL TANKS $\ldots \ldots \ldots \ldots \ldots \ldots \ldots \ldots \ldots \ldots \ldots \ldots \ldots \ldots \ldots$

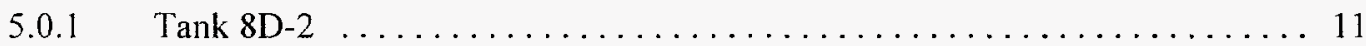

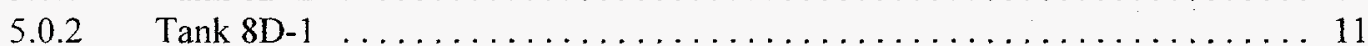

5.1 External Corrosion . . . . . . . . . . . . . . . . . . . . . . . . 11

5.1.1 Microbiologically Influenced Corrosion $\ldots \ldots \ldots \ldots \ldots \ldots \ldots \ldots \ldots$

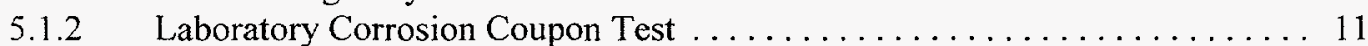

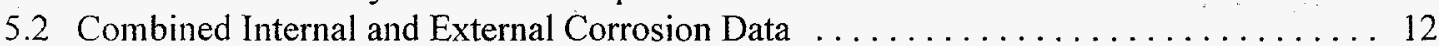

5.2.1 Tank-roof Cut-out Data . . . . . . . . . . . . . . . . . . . . . . 12

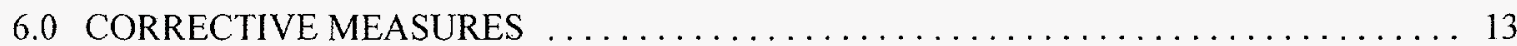

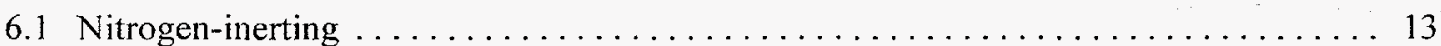

6.2 Laboratory Nitrogen-inerting Test Results $\ldots \ldots \ldots \ldots \ldots \ldots \ldots \ldots \ldots \ldots \ldots \ldots \ldots$

6.3 Abatement of Water Infiltration . . . . . . . . . . . . . . . . . . . . . . 17

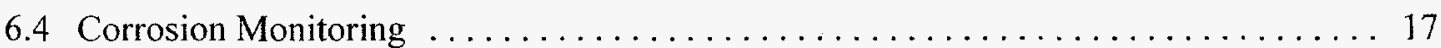

7.0 SAFETY MANAGEMENT PHILOSOPHY FOR TANKS 8D-1 AND 8D-2 $\ldots \ldots \ldots \ldots$

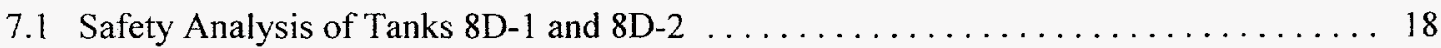

7.2 Defense-in-depth Layers for $8 \mathrm{D}-1$ and $8 \mathrm{D}-2 \ldots \ldots \ldots \ldots \ldots \ldots \ldots \ldots \ldots \ldots \ldots \ldots \ldots \ldots \ldots$

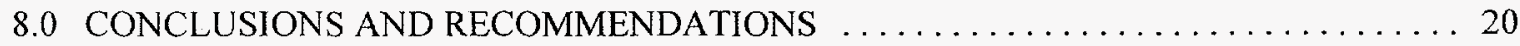

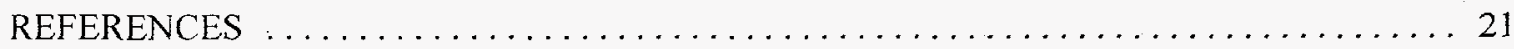




\section{LIST OF FIGURES}

Figure

$\underline{\text { Page }}$

1. Diagram of Neutralized High-Level Waste Tank $\ldots \ldots \ldots \ldots \ldots \ldots \ldots \ldots \ldots \ldots \ldots$

2. Internal Diagram and Vault Configuration of Neutralized High-Level Waste

Tanks $8 \mathrm{D}-1$ and $8 \mathrm{D}-2$

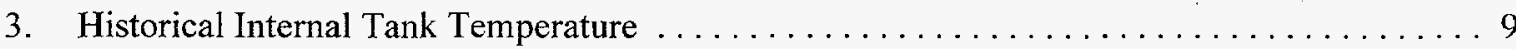

4. Carbon Steel Corrosion Test Apparatus in Perlite/Water Mixture. One Tank is

Purged with Nitrogen Gas and the Other with Air. Test Conducted @ 30 C,

Purge@100 cc/min., Dissolved Oxygen in Water@1 p.m. in the Nitrogen

Chamber and 6-8 p.m. (saturated) in the Air Chamber.

5. Calculated Uniform Corrosion Rates for Nitrogen-inerted vs Air-purged Specimens@30E C. Rates are Adjusted for the Submerged Area of the Specimen. Corrosion in the Vapor Space was Negligible in all Cases for the 18-month Test.

\section{LIST OF TABLES}

$\underline{\text { Table }}$

$\underline{\text { Page }}$

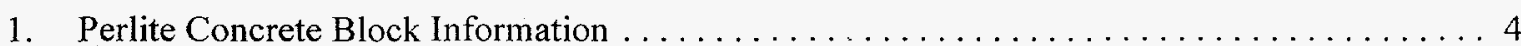

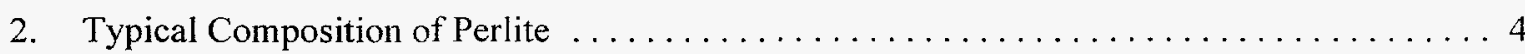

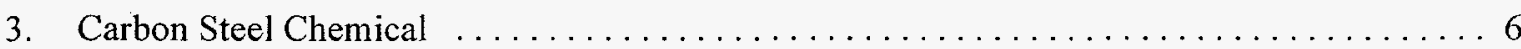

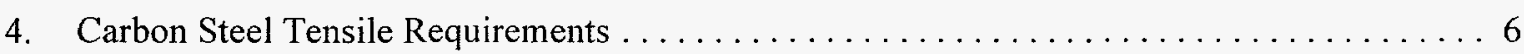

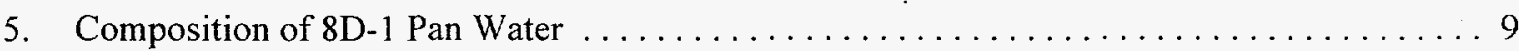

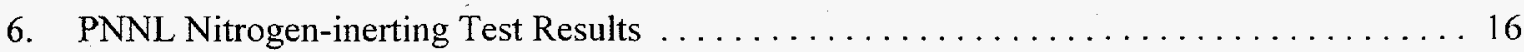




\section{ACKNOWLEDGMENTS}

The author would like to thank D. C. Meess, Manager of Vit/IRTS Operations Engineering; K. F. Richter and D. J. Stroud of West Valley Nuclear Services Co., Inc. for their guidance; Dr. J. R. Divine, ChemMet Ltd. PC; Dr. R. E. Westerman and M. R. Elmore, Battelle Pacific Northwest National Laboratory, Richland, WA; and R. H. Kunig, Westinghouse Science and Technology Center, Monroeville, PA, for discussions on the materials they provided. The author also acknowledges J. C. Cwynar who has commented on the manuscript and contributed a section on safety analysis. Thanks are also extended to WVNS managers P. J. Valenti, C. J. Winkler, and R. A. Humphrey for their valuable comments. Support of Ms. P. A. Abrams, DOE- WV, is very much appreciated. Last, but not least, thanks are extended to $\mathrm{D}$. Gingold for providing editing services throughout and K. Gerwitz, $\mathrm{S}$. Tatlow, and $\mathrm{C}$. Habicht for typing the manuscript. 


\begin{abstract}
As the West Valley Demonstration Project (WVDP) continues vitrification operation and begins decontamination activities, it is vital to continue to maintain the integrity of the high-level waste tanks and prevent further corrosion that may disrupt the operation. This report describes the current operational status and some corrosion concerns with corresponding control measure recommendations.
\end{abstract}

Keywords: Corrosion, Carbon Steel, HLW Tanks, Groundwater 


\subsection{INTRODUCTION}

The only commercial nuclear fuel reprocessing facility ever to operate in the United States is located on approximately 200 acres of the 3,345-acre Western New York Nuclear Service Center (WNYNSC) near West Valley, New York. The WNYNSC is owned by New York State through the New York State Energy Research. and Development Authority (NYSERDA).

The commercial nuclear fuel reprocessing facility was leased to a private company and operated from 1966 to 1972 to recover useable uranium and plutonium. Approximately 640 tons of spent nuclear fuel were reprocessed generating about 600,000 gallons of liquid, high-level radioactive waste (HLW). The HLW was placed in storage in an underground tank (8D-2) contained within a concrete vault. Tank 8D-1, an identical tank, was used as the spare backup tank.

In 1980, the West Valley Demonstration Project (WVDP) Act was signed by the President of the United States to become Public Law 96-368. The Act directs the Department of Energy (DOE) to solidify the HLW stored at the site into a durable, solid form suitable for shipment to a federal repository; clean and close the facilities used; and dispose of the low-level and transuranic wastes collected during Project operations.

In 1981 DOE selected West Valley Nuclear Services Company, Inc. (WVNS), a wholly owned subsidiary of Westinghouse Electric Corporation, as prime Project contractor. DOE and WVNS assumed operational control of the site in 1982 .

Within Tank 8D-2, the HLW had separated into two phases: a relatively clear liquid and a thick layer of solid sludge. The stabilization of this waste was planned to be conducted in two stages: 1) pretreatment to separate the salts from the radioactive components, and 2) removal of the HLW from 8D-2 and vitrification into a borosilicate glass waste form using a slurry-fed ceramic melter (SFCM).

The pretreatment consisted of processing the liquid phase of the waste through an ion-exchange process using zeolite (a synthetic, sodium aluminosilicate mineral) ion-exchange media. The sludge in the bottom of 8D-2 was then mobilized and mixed with water (washed) to dissolve sulfates and other salts. The wash water was then processed through the zeolite ion-exchange system. Pretreatment operations were started in 1988 and completed in 1995 resulting in approximately 20,000 drums of cemented low-level waste (LLW).

During the second stage of stabilization, the HLW mixture (consisting of the sludge and the zeolite) is removed from Tank 8D-2 and transferred to the Vitrification Facility where glass-forming chemicals are added and the mixture is fed to a 52-ton, joule-heated ceramic melter. The melter is then heated to approximately 2,000E F $(1,093 \mathrm{E} \mathrm{C})$ to produce a homogeneous molten waste/glass blend that is cast into 2 -foot $(0.6 \mathrm{~m})$ diameter by 10 -foot $(3.0 \mathrm{~m})$ long stainless steel canisters. The vitrification system began operation in June, 1996 and will produce approximately 250 glass-filled canisters by June 1998. To date, approximately 90 canisters have been completed.

For various reasons to be discussed later, groundwater has infiltrated the concrete vault and leak detection pan surrounding Tanks $8 \mathrm{D}-1$ and $8 \mathrm{D}-2$, subjecting the tanks and pans to a mildly corrosive environment for approximately 31 years. The purpose of this report is to: 1) discuss the results of corrosion tests and characterization of tank samples (taken after 24 years of exposure);2) describe protective and mitigative safety systems for tank leakage; and 3) discuss corrective measures being taken to minimize the effects of corrosion and extend the service life of the tanks. 


\subsection{TANK DESIGN DESCRIPTION}

Tanks 8D-1 and 8D-2 are for all practical purposes identical in design. Both were designed to store neutralized liquid HLW produced during the reprocessing of spent nuclear fuel. Tank $8 \mathrm{D}-2$ was designated as the primary storage tank with $8 \mathrm{D}-1$ serving as a redundant spare tank. The system design provided the capability to transfer contents between tanks should it become necessary.

Each tank is a reinforced single-wall carbon steel vessel, approximately 70 feet $(21.3 \mathrm{~m})$ in diameter by 27 feet $(8.2 \mathrm{~m})$ high, with a capacity of 750,000 gallon $(2,800,000 \mathrm{l})$ (Figure 1), fully contained within a 2 - $\mathrm{ft}(0.6 \mathrm{~m})$ thick reinforced concrete underground vault. The vessels of Tanks $8 \mathrm{D}-1$ and $8 \mathrm{D}-2$ each rest on two layers of perlite blocks. The blocks consist of a mixture of portland cement and expanded-perlite (Table 1). ${ }^{1}$ The joints between the blocks were filled with loose expanded perlite after the blocks were put in place. Below the two courses of perlite, each 6 -inch $(15-\mathrm{cm})$ thick, is a 3 -inch $(8-\mathrm{cm})$ thick bed of pea gravel. The pea gravel itself is contained by a carbon steel pan that rests on another 3 -inch $(8-\mathrm{cm})$ thick bed of pea gravel placed on the floor of the main concrete containment vault (Figure 2). The block layers are centered in the pan and bound by a steel band. The assembled perlite blocks form a platform 72.5 feet $(22.1 \mathrm{~m})$ in diameter by 12 inch $(30 \mathrm{~cm})$ high. Information on the perlite composition is shown in Table $2 .^{2}$

The tanks were field-fabricated from carbon steel plates (ASTM A-201-64, Grade A, Firebox), ranging in thickness from 0.437 to 0.656 inch, welded together to form tanks with six internal column-clearance pipes (each 4 feet [1.2 $\mathrm{m}]$ in diameter) that extend between the tank bottom and the roof (Figure 2). The steel composition and tensile requirements ${ }^{3}$ are shown in Tables 3 and 4 , respectively. 


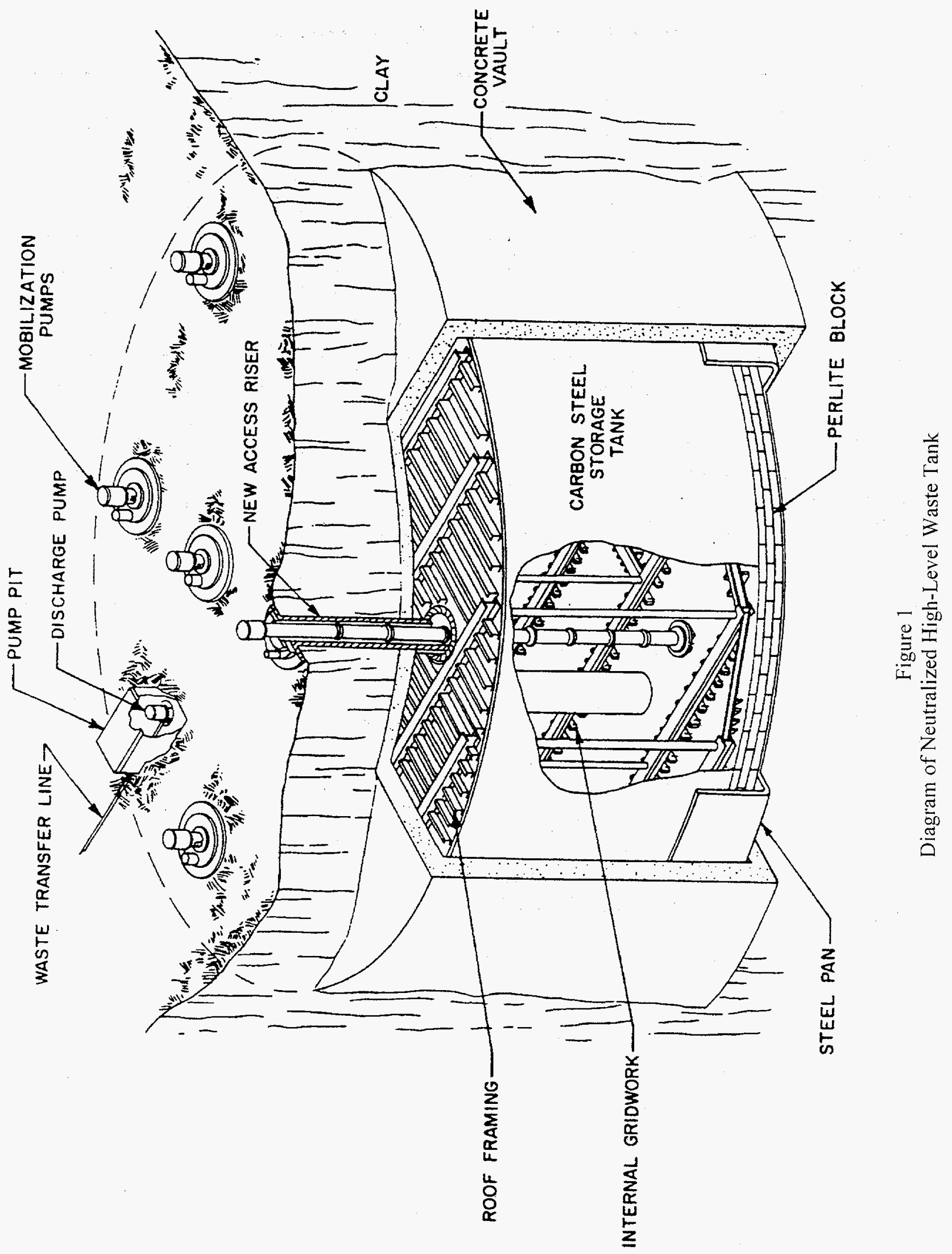


Table 1. Perlite Concrete Block Information ${ }^{1}$

\begin{tabular}{|c|c|c|}
\hline Characteristic & Units & Data \\
\hline $\begin{array}{l}\text { Mix proportion by volume: } \\
\text { Type I or II portland cement } \\
\text { Perlite } \\
\text { Water } \\
\text { Air entraining agent } \\
\end{array}$ & $\begin{array}{l}\text { cu. ft }\left(\mathrm{m}^{3}\right) \\
\text { cu. } \mathrm{ft}\left(\mathrm{m}^{3}\right) \\
\text { US gallon (l) } \\
\text { US pint (l) }\end{array}$ & $\begin{array}{c}1(0.028) \\
5(0.14) \\
11(41.5) \\
1.25(0.6)\end{array}$ \\
\hline $\begin{array}{l}\text { Density of perlite concrete block } \\
\text { Density of loose perlite fill }\end{array}$ & $\begin{array}{l}\mathrm{lb} / \mathrm{cu} \cdot \mathrm{ft} \cdot\left(\mathrm{kg} / \mathrm{m}^{3}\right) \\
\mathrm{lb} / \mathrm{cu} \cdot \mathrm{ft}\left(\mathrm{kg} / \mathrm{m}^{3}\right)\end{array}$ & $\begin{array}{c}30-40(480-640) \\
4-6(64-96)\end{array}$ \\
\hline Thermal conductivity $(6)$ & $\begin{array}{c}\mathrm{Btu} \cdot \mathrm{in} / \mathrm{hr} \cdot \mathrm{ft}^{2} \cdot \mathrm{F} \\
(\mathrm{w} / \mathrm{m} \cdot \mathrm{K})\end{array}$ & $\begin{array}{c}0.47-0.85 \\
(0.07-0.12) \\
\end{array}$ \\
\hline 28-day cured compressive strength, minimum & psi (MPa) & $\geq 270(1.9)$ \\
\hline $\begin{array}{l}\text { Size and quantity used: } \\
7-5 / 8 \times 5-5 / 8 \times 15-5 / 8 \text { block (inch) } \\
\quad(19.4 \times 14.3 \times 39.7 \mathrm{~cm}) \\
7-5 / 8 \times 5-5 / 8 \times 7-5 / 8 \text { block (inch) } \\
\quad(19.4 \times 14.3 \times 19.4 \mathrm{~cm}) \\
\text { Loose perlite fill }\end{array}$ & $\begin{array}{c}\text { ea. } \\
\text { ea. } \\
\text { cu. } \mathrm{ft}\left(\mathrm{m}^{3}\right)\end{array}$ & $\begin{array}{c}17,900 \\
1,000 \\
350(9.9)\end{array}$ \\
\hline
\end{tabular}

Table 2. Typical Composition of Perlite ${ }^{2}$

\begin{tabular}{|c|c|}
\hline Composition & wt. \% \\
\hline $\mathrm{SiO}_{2}$ & $72-75$ \\
\hline $\mathrm{Al}_{2} \mathrm{O}_{3}$ & $12-14$ \\
\hline $\mathrm{Na}_{2} \mathrm{O}$ & $3-4$ \\
\hline $\mathrm{K}_{2} \mathrm{O}$ & $4-5$ \\
\hline $\mathrm{CaO}$ & $0.5-1$ \\
\hline $\mathrm{Fe}$ (total) & $0.5-1$ \\
\hline $\mathrm{H}_{2} \mathrm{O}$ & $3-5$ \\
\hline
\end{tabular}




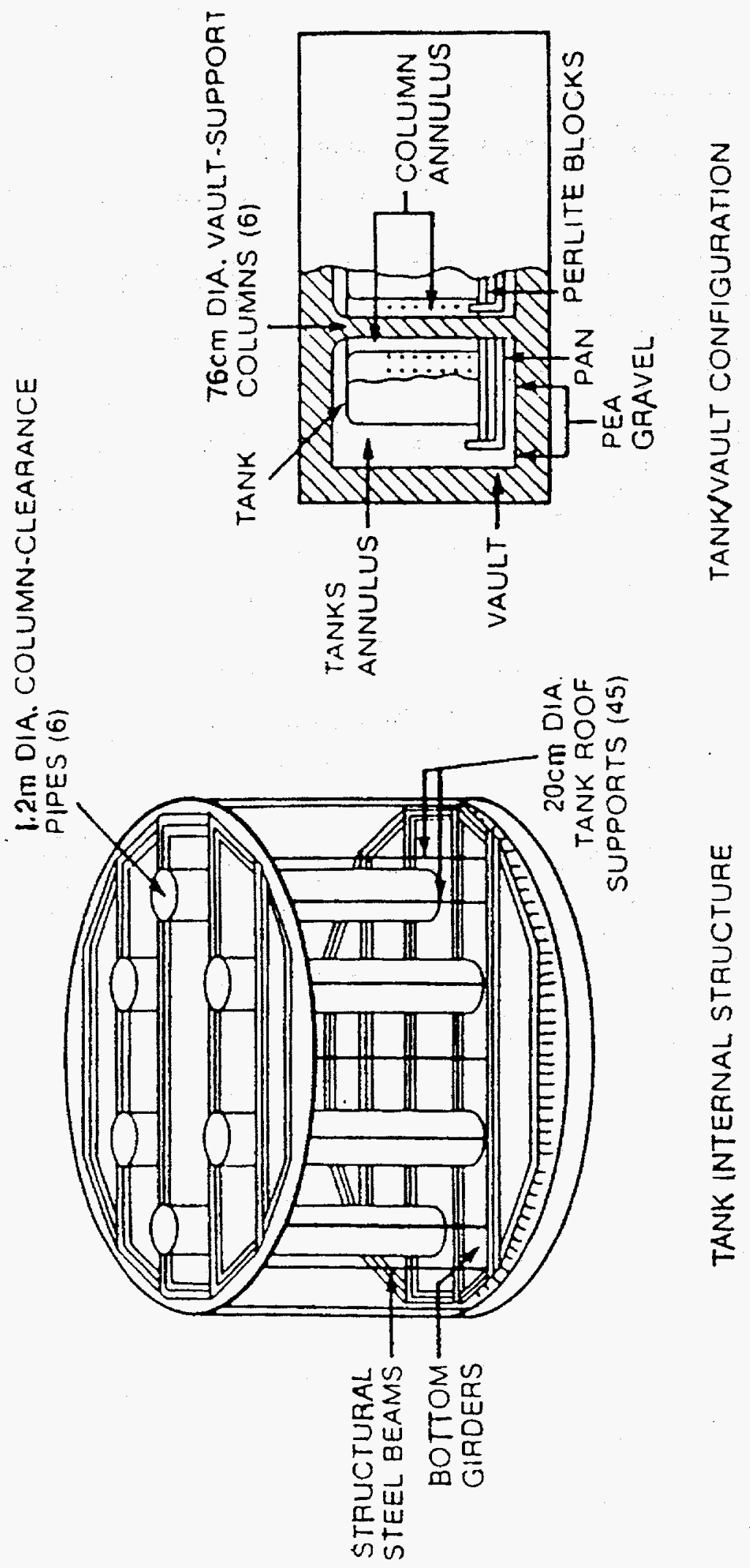


Table 3. Carbon Steel Chemical ${ }^{3}$

\begin{tabular}{|l|c|}
\hline \multicolumn{1}{|c|}{ Constituent } & Grade "A" Specification \\
\hline Carbon, \% maximum, plates \# 1 inch $(25 \mathrm{~mm})$ & 0.20 \\
\hline Manganese, \% maximum & 0.80 \\
\hline Phosphorus, \% maximum, firebox & 0.035 \\
\hline Sulfur, \% maximum, firebox & 0.04 \\
\hline Silicon, \%, Ladle analysis & 0.15 to 0.30 \\
Check analysis & 0.13 to 0.33 \\
\hline
\end{tabular}

Table 4. Carbon Steel Tensile Requirements

\begin{tabular}{|l|c|}
\hline \multicolumn{1}{|c|}{ Physical Property } & Grade "A" Specification \\
\hline Tensile strength, psi (MPa) & 55,000 to 65,000 (379 to 448) \\
\hline Yield point in 8 inch $(200 \mathrm{~mm}), \%$ minimum, firebox & 25 \\
\hline Elongation in 2 inch $(50 \mathrm{~mm}), \%$ minimum, firebox & 29 \\
\hline
\end{tabular}




\subsection{CONSTRUCTION HISTORY}

Construction of Tanks 8D-1 and 8D-2 began in 1964 and was completed in 1965. The tanks were both stressrelieved after construction, thus reducing the potential for stress corrosion cracking. Toward the end of construction in 1965 both vaults floated.

\subsection{Tank 8D-1}

As a result of the vault flotation, Tank $8 \mathrm{D}-1$ is tilted one degree from vertical which equates to a $16-7 / 16$ inch $(41.8 \mathrm{~cm})$ vertical displacement for a 78.6 foot $(24.0 \mathrm{~m})$ diameter vault. In 1986 , modifications were made to Tank $8 \mathrm{D}-1$ to install new risers for the mounting of zeolite mobilization pumps and waste processing tanks to be used in the pretreatment of the HLW. Since then, the entry of groundwater (from rain) through the roof penetrations of the vaults into the annulus region between the exterior of the tanks and the inner wall of the concrete vaults has increased to approximately 100 to 200 gallons/day. Water drips down on the tank top, runs down the exterior wall of the tank, and collects in the pan. The pan water is periodically pumped out; however it is expected that the perlite blocks retain a considerable amount of moisture. It is suspected that the external surfaces of the lower portions of the tank have been in a moist condition since its construction in 1965 . The $8 \mathrm{D}-1$ containment pan is sound and does not show any sign of loss of containment.

\subsection{Tank 8D-2}

Tank $8 \mathrm{D}-2$ is only tilted about 0.14 degree due to the vault flotation, resulting in a $2-1 / 4$ inch vertical displacement. Furthermore, the 8D-2 pan did not pass its hydrostatic fill test and could not be repaired due to structural obstacles. New risers to house sludge mobilization pumps were installed in Tank 8D-2 in 1986. Water infiltrates Tank $8 \mathrm{D}-2$ in a manner similar to Tank $8 \mathrm{D}-1$, but at a much higher rate (500 to 800 gallons/day). The bottom of the carbon steel tank has been in contact with groundwater and perlite block and has been alternately exposed to water and air whenever the water is pumped out. Water has apparently infiltrated the concrete vault at a higher rate since new pump mobilization risers were installed in 1986 . The lower portion of Tank 8D-2 is also suspected to have been in a moist condition since 1965 . 


\subsection{CORROSION ENVIRONMENT}

Tanks 8D-1 and 8D-2 and their respective pans have been exposed to water and high humidity for approximately 31 years. The rate of external corrosion of the tanks is influenced by the content of chemical species such as $\mathrm{Ca}^{+}, \mathrm{Cl}^{-}, \mathrm{NO}_{3}^{-}, \mathrm{SO}_{4}{ }^{2-}$, and carbonate in the pan water. This rate is also influenced by $\mathrm{pH}$, temperature, and electrical conductivity of the pan water. These could result in stress corrosion cracking (SCC), pitting, general corrosion, and microbiologically influenced corrosion.

\subsection{Pan Water Composition}

The composition of the pan water obtained from the Tank $8 \mathrm{D}-1$ vault was analyzed by the Pacific Northwest National Laboratory (PNNL). ${ }^{4}$. The results of the analysis are shown in Table 5.

Table 5. Composition of 8D-1 Pan Water ${ }^{4}$

\begin{tabular}{|c|c|}
\hline Chemical Species & Concentration, $\mathrm{mg} / \mathrm{l}$ \\
\hline $\mathrm{Al}$ & 0.04 \\
\hline $\mathrm{Ca}$ & 8.4 \\
\hline $\mathrm{K}$ & 115 \\
\hline $\mathrm{Mg}$ & 2.8 \\
\hline $\mathrm{Na}$ & 99 \\
\hline $\mathrm{Si}$ & 31.5 \\
\hline $\mathrm{B}$ & 0.1 \\
\hline $\mathrm{Cl}$ & 10.7 \\
\hline Nitrate $\left(\mathrm{NO}_{3}{ }^{-}\right)$ & 3.26 \\
\hline Sulfate $\left(\mathrm{SO}_{4}{ }^{2-}\right)$ & 206 \\
\hline Total carbon & 34.4 \\
\hline Inorganic carbon & 32.6 \\
\hline Total organic carbon & 2.1 \\
\hline $\mathrm{pH}$ & 9.8 \\
\hline Conductivity, $\mu \mathrm{mho} / \mathrm{cm}$ & 925 \\
\hline
\end{tabular}

\subsection{Temperature of Tank Wall and Pan Water}

The historical internal temperature of the tanks is given in Figure 3. It is assumed that the external wall temperature of the tanks is only slightly less. The temperature range of Tank $8 \mathrm{D}-1$ is $70 \mathrm{E} \mathrm{F}(21.1 \mathrm{E} \mathrm{C})$ to $90 \mathrm{E} \mathrm{F} \mathrm{(32.2E} \mathrm{C).} \mathrm{The}$ temperature range of Tank $8 \mathrm{D}-2$ is $120 \mathrm{E} \mathrm{F}(50 \mathrm{E} \mathrm{C})$ to $170 \mathrm{E} \mathrm{F}(76.6 \mathrm{E} \mathrm{C})$ in the sludge and $20 \mathrm{E} \mathrm{F}(11 \mathrm{E} \mathrm{C})$ to $40 \mathrm{E} \mathrm{F}(22.2 \mathrm{E}$ C) lower in the vapor space. The pan temperature of Tank $8 \mathrm{D}-1$ is $65 \mathrm{E} \mathrm{F}(18.3 \mathrm{E} \mathrm{C})$ and that of $8 \mathrm{D}-2$ is $125 \mathrm{E} \mathrm{F}(51.6 \mathrm{E} \mathrm{C})$. Thus, the tank wall may experience a slightly higher corrosion rate than the vault pan. 


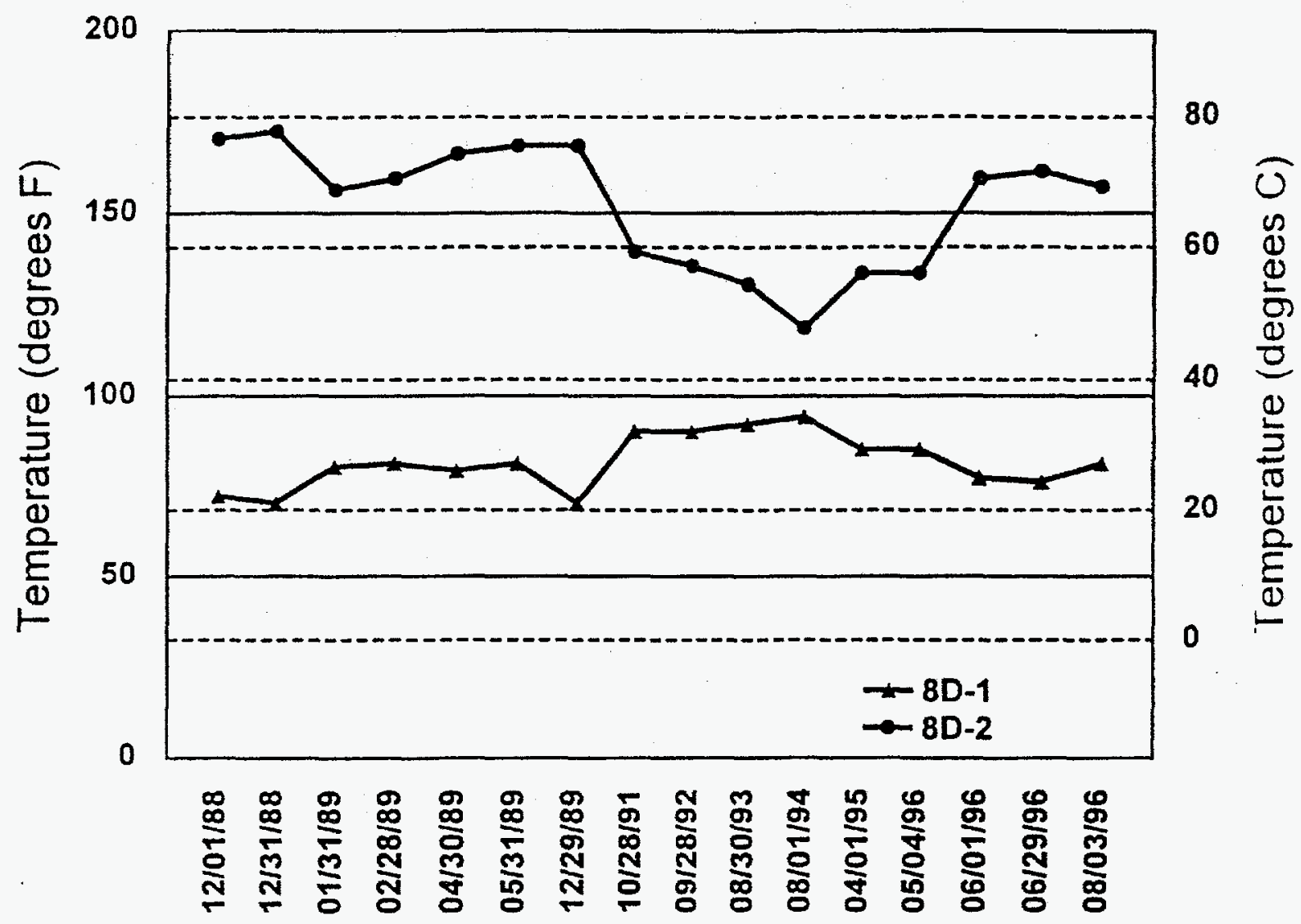

Figure 3

Historical Internal Tank Temperature 


\subsection{Conductivity of Pan Water}

The conductivity and the concentration of sulfate in the pan water suggest that the water could be corrosive. The relatively low inorganic carbon concentration, assumed to represent a combination of carbonate and bicarbonate, suggests scale formation will be low, which also implies that the water could be corrosive. On the other hand, the high $\mathrm{pH}$ will tend to reduce the corrosivity. If it is assumed that the $32.3 \mathrm{mg} / \mathrm{lof}$ inorganic carbon consisted of $30 \mathrm{mg} / 1 \mathrm{HCO}_{3}{ }^{-}$and $2.3 \mathrm{mg} / 1 \mathrm{CO}_{3}{ }^{2-}$, then the Langelier Saturation Index ${ }^{8}$ can be calculated to be 0.9 , or moderately noncorrosive.

This corrosion evaluation is consistent with that provided by the use of a Pourbaix diagram. ${ }^{5}$ At a $\mathrm{pH}$ of 9.8 , the expected equilibrium products are stable oxides. Nevertheless, all of these evaluations are based on thermodynamic arguments and do not take into consideration the localized effects caused by stagnant regions, crevices, corrosion-product films formed on the steel surface, or cyclic operating conditions. In these localized areas, a variation in the concentration of oxygen occurs or a minor amount of other active species can migrate that can further change the local composition. As a result, accelerated pitting corrosion could occur. 


\subsection{CORROSION OF CARBON STEEL TANKS}

At present, both HLW Tanks $8 \mathrm{D}-1$ and $8 \mathrm{D}-2$ are effectively containing the high-level radioactive wastes. It is also clear that the pan of Tank 8D-1 (375 mils thick) has not been penetrated.

\subsubsection{Tank 8D-2}

In 1966, Tank 8D-2 began to receive waste and, in addition, corrosion coupons were installed. After 10 years of exposure the samples were analyzed. The general corrosion rate of the samples located in the vapor phase was 0.53 mpy and for those in the liquid phase $0.04 \mathrm{mpy}^{10}$

In September 1993, laboratory tests were conducted to simulate sludge washing conditions in Tank 8D-2. Test results after 9 months show an average general corrosion rate of 0.55 mpy in vapor and 0.05 mpy in liquid. This is in good agreement with the tank corrosion coupons noted above.

Between January 1992 and January 1996, corrosion probe (V6) readings in the vapor space show 1 mpy and the sludge probe $(\mathrm{S} 1)$ readings show $0.06 \mathrm{mpy}{ }^{6,11}$

\subsubsection{Tank 8D-1}

In December 1988, corrosion coupons were installed in Tank 8D-1 and subsequently inspected after 272 days." In January 1990, these coupons were re-exposed for 1,640 additional days and removed and inspected in July 1994. Characterization results show that the average general corrosion rate in the liquid phase was 0.47 mpy and 0.49 mpy in the vapor phase. ${ }^{11}$

Based on these data and the trends observed to date, the internal corrosion rate of both tanks is not considered significant with the current corrosion control program maintaining a high $\mathrm{pH}(10.5$ to 11.5$)$ and a $\mathrm{NO}_{2} / \mathrm{NO}_{3}$ ratio in the nonpitting region. Thus, the concern for evaluating overall tank integrity has been focused on external tank corrosion.

\subsection{External Corrosion}

\subsubsection{Microbiologically Influenced Corrosion}

Because of the presence of nitrate in the pan water at the concentrations shown in Table 5, an enhancement of microbiologically influenced corrosion (MIC) is feasible. The high sulfate values suggest that the presence of sulfate reducing bacteria (SRB) could be viable under anaerobic conditions if a source of organic material were available. However, results of the measured bacteria counts in August 1996 have shown that the SRB content is less than 100 cells $/ \mathrm{ml}^{6}$, which is not expected to be of concern, particularly with the lack of organic material to serve as nutrients.

\subsubsection{Laboratory Corrosion Coupon Test}

The PNNL conducted short-term (2 $1 / 2$ years) corrosion coupon tests simulating Tanks 8D- 1 and $8 D-2$ external

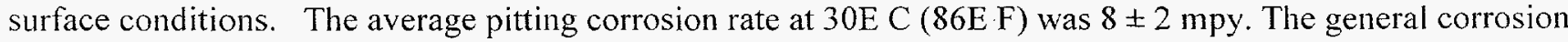
rate based on the average weight loss in water at $30 \mathrm{E} \mathrm{C} \mathrm{(86E} \mathrm{F)} \mathrm{was} \mathrm{about} 2.3 \pm 0.4$ mpy. Thus, at the $30 \mathrm{E} \mathrm{C}$ ( $86 \mathrm{E} \mathrm{F}$ ) outside tank temperature, the corrosion-to-pitting factor is about 3.5 ( $8 \mathrm{mpy} \div 2.3 \mathrm{mpy})$ in water. This is a close match to the Handbook data, ${ }^{9,14}$ of 3.5 for the scaled carbon steel for long-term corrosion (over 10 years) in water at room temperature. However, a pitting factor of 5 ( $15 \mathrm{mpy} \div 3 \mathrm{mpy}$ ) was calculated for coupons exposed at the higher temperature (194E F [90E C] in the vapor phase). These data represent relatively short-time tests (compared with a 31 -year-old tank) and the corrosion rate is expected to decrease when the samples are exposed over longer times (greater than 10 years). ${ }^{7,8}$ It was noteworthy that the maximum pitting corrosion rate was $28 \mathrm{mpy}$ in the vapor phase at $194 \mathrm{E} \mathrm{F} \mathrm{(90E} \mathrm{C)} \mathrm{during} \mathrm{the} 2 \mathrm{l} / 2$ - year period. 


\subsection{Combined Internal and External Corrosion Data}

\subsubsection{Tank-roof Cut-out Data}

During the pump riser installation work between October 1986 and April 1987, six pieces of 28-inch (71 cm) diameter disks were removed from the tank roof of $8 \mathrm{D}-2$ and the remaining metal thickness was measured after descaling. These samples provide tank corrosion data for 22 years of exposure. The fifty data points measured were analyzed statistically. A mean general corrosion rate of 2 mpy was calculated with a two sigma value of 3.31 mpy. 


\subsection{CORRECTIVE MEASURES}

The corrosion data discussed above illustrates the importance of lowering the general and pitting corrosion rates. The WVDP is currently reducing the corrosion rate by lowering the oxygen level in the vaults through the use of a nitrogen-inerting system. The abatement of water intrusion into the vaults is also in progress. To assess the effectiveness of these corrective measures, corrosion coupons have been installed in the vault of each tank.

\subsection{Nitrogen-inerting}

At ambient temperatures, oxygen and moisture are necessary factors for the corrosion of iron or carbon steel in neutral or near-neutral environments. Oxygen alone or water free of dissolved oxygen does not corrode carbon steel to any practical extent. The rate of corrosion is, in general, roughly proportional to the concentration of the oxygen present. In addition, oxygen can cause localized attack through the formation of differential aeration cells. Such cells are formed whenever iron is in contact with an aerated solution at one place and with an oxygen-deficient solution elsewhere. The oxygen-deficient areas become anodes and, therefore, more actively corrode. Differential aeration cells commonly account for localized corrosion (pitting) under rust layers on carbon steel. Accelerated corrosion occurs in open crevices or causes corrosion near the water line of submerged steel structures. The presence of salts (such as chlorides) or an increase in temperature can accelerate the corrosion.

To stop or slow corrosion, there are essentially three approaches: eliminate the electrolytic bridge between the two electrodes, modify the cathodic reaction, or modify the anodic or corrosion reaction. The approach selected was the removal of the cathode reactant, oxygen, by purging the system with nitrogen.

\subsection{Laboratory Nitrogen-inerting Test Results ${ }^{12}$}

PNNL performed corrosion tests on carbon steel coupons (ASTM 201, Grade A, Firebox) that were cut out of the Tank 8D-1 roof. Two sets of coupons were exposed in separate chambers as shown in Figure 4 . The samples were partially placed in perlite granules and water (Tank $8 \mathrm{D}-1$ vault water supplied by WVNS) to simulate corrosion conditions for the bottom of Tank $8 \mathrm{D}-1$. One chamber was purged with air and the other with nitrogen. The vault water was saturated with dissolved oxygen (6-8 p.m.) in the air chamber and contained approximately $1 \mathrm{p} . \mathrm{m}$. dissolved oxygen in the nitrogen chamber. The gas composition in the nitrogen chamber was approximately 99.5 vol. \% nitrogen and $0.5 \mathrm{vol} . \%$ oxygen. The test results are presented in Figure 5 and Table 6.

Corrosion was limited to the submerged half of each specimen. Negligible corrosion was observed in the vapor phase. The total number of pits was greatly reduced on the submerged surface for the nitrogen-exposed coupons when compared to the air-exposed coupons. In the locations where the perlite tightly adhered to the coupons, the maximum pit depth was the same for both environments.

The above test results indicate that inerting the vault atmosphere with nitrogen, stopping water intrusion into the vaults, and lowering the moisture content of the vault atmosphere to less than approximately $40 \%$ relative humidity, will minimize pitting problems. Under this relatively dry condition, the inert gas can more readily penetrate to the center of the tank bottom and lower the oxygen partial pressure to help control corrosion. The WVDP has installed a nitrogen-inerting system for both vaults in July 1996 and it is currently in operation. 


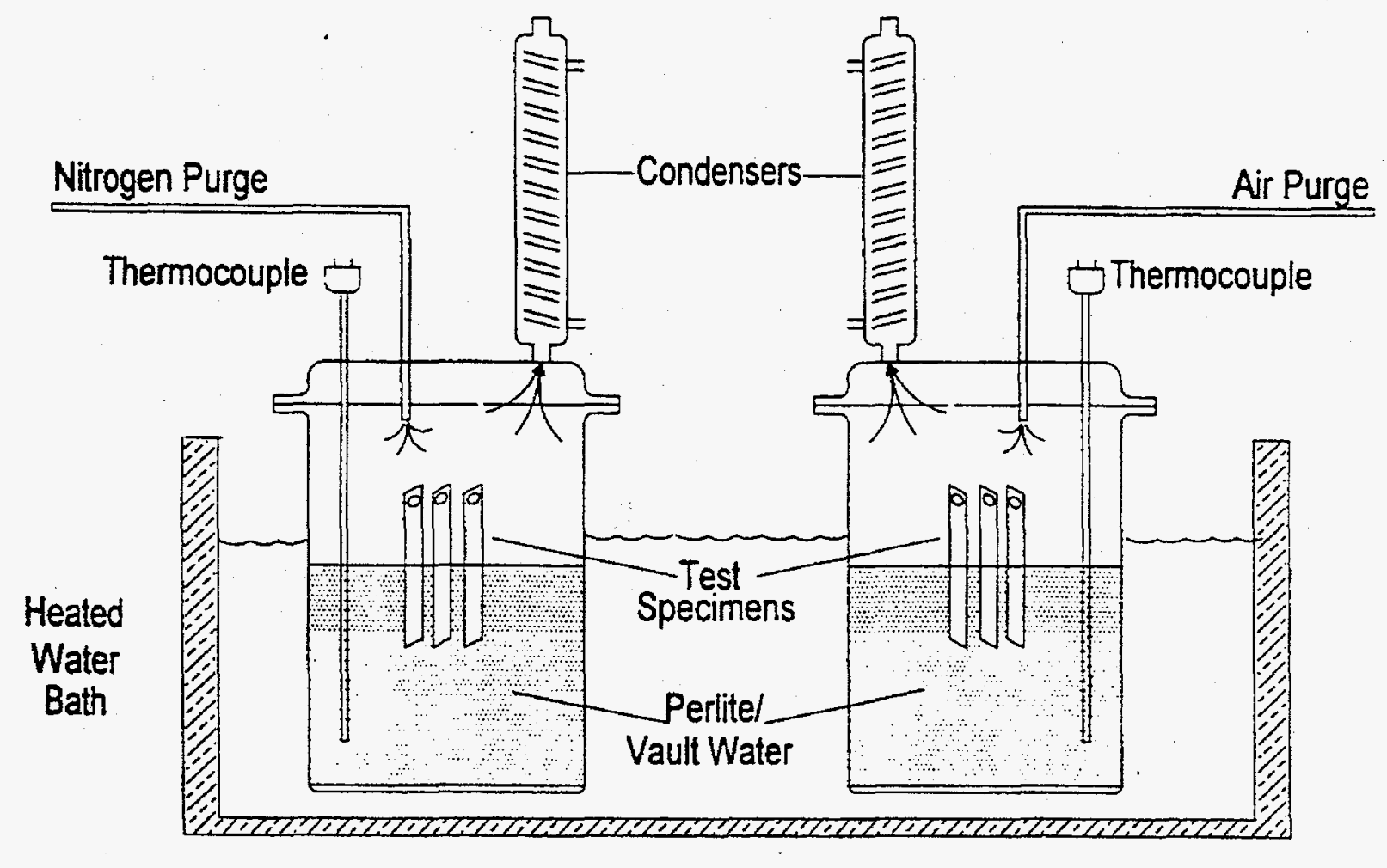

Figure 4

Carbon Steel Corrosion Test Apparatus in Perlite/Water Mixture. One Tank is Purged with Nitrogen Gas and the Other with Air. Test Conducted @30 C, Purge@100 cc/min., Dissolved Oxygen in Water@1 p.m. in the Nitrogen Chamber and 6-8 p.m. (saturated) in the Air Chamber. 


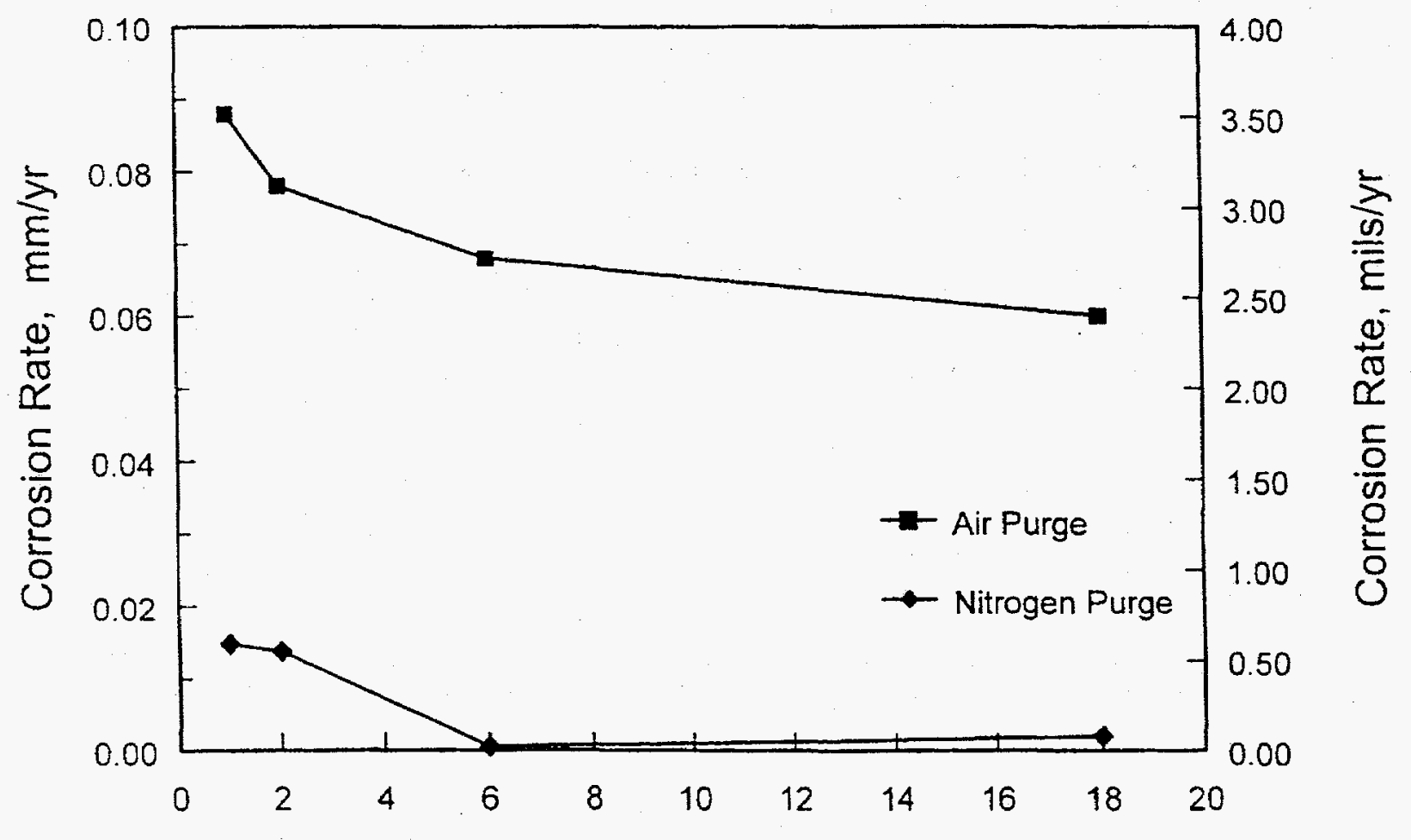

Exposure Time, months

Figure 5

Calculated Uniform Corrosion Rates for Nitrogen-inerted vs Air-purged Specimens @ 30E C. Rates are Adjusted for the Submerged Area of the Specimen. Corrosion in the Vapor Space was Negligible in all Cases for the 18-month Test. 
Table 6. PNNL Nitrogen-inerting Test Results ${ }^{12}$

Test Temperature: $30^{\circ} \mathrm{C}$; Continuous Purge of Vessel $@ 100 \mathrm{cc} / \mathrm{min}$.;

Multiple Specimens in each of 2 Vessels; Half Submerged in Perlite/Water.Dissolved Oxygen in Water@1 p.m. in the Nitrogen Chamber and 6-8 p.m. (saturated) in the Air Chamber

\begin{tabular}{|c|c|c|c|c|c|}
\hline \multirow[b]{2}{*}{ Purge Gas } & \multirow[b]{2}{*}{ Exposure } & \multirow{2}{*}{$\begin{array}{l}\text { Specimen } \\
\text { ID }\end{array}$} & \multicolumn{2}{|c|}{ Corrosion Rate (mpy) } & \multirow{2}{*}{$\begin{array}{c}\text { Observations \& Pit } \\
\text { Depths } \\
\text { mils }(\mathrm{mm})\end{array}$} \\
\hline & & & $\begin{array}{l}\text { Measured (a) } \\
\mathrm{mpy}(\mathrm{mm} / \mathrm{y})\end{array}$ & $\begin{array}{l}\text { Adjusted (a) } \\
\mathrm{mpy}(\mathrm{mm} / \mathrm{y})\end{array}$ & \\
\hline Nitrogen & 1 month & X003 & $0.315(0.008)$ & $0.590(0.015)$ & \multirow{3}{*}{$\begin{array}{l}\text { No pitting on vapor } \\
\text { or submerged halves }\end{array}$} \\
\hline Nitrogen & 1 month & X023 & $0.275(0.007)$ & $0.551(0.014)$ & \\
\hline Nitrogen & 1 month & $\mathrm{X} 018$ & $0.315(0.008)$ & $0.669(0.017)$ & \\
\hline Air & 1 month & X032 & $1.889(0.048)$ & $3.778(0.096)$ & \multirow{3}{*}{$\begin{array}{l}\text { No pitting on vapor } \\
\text { or submerged halves }\end{array}$} \\
\hline Air & 1 month & X033 & $1.653(0.042)$ & $3.266(0.083)$ & \\
\hline Air & 1 month & $\mathrm{X} 048$ & $1.653(0.042)$ & $3.305(0.084)$ & \\
\hline Nitrogen & 2 months & $\mathrm{X} 046$ & $0.275(0.007)$ & $0.551(0.014)$ & \multirow{6}{*}{$\begin{array}{l}\text { Few shallow pits } \\
<0.984 \mathrm{mil} \\
(<0.025 \mathrm{~mm}) \text { on } \\
\text { submerged halves } \\
\text { Slight vapor and } \\
\text { interface pitting, } \\
\text { heavier submerged } \\
\text { corrosion }>0.984 \mathrm{mil} \\
(>0.025 \mathrm{~mm})\end{array}$} \\
\hline Nitrogen & 2 months & $\mathrm{X} 016$ & $0.315(0.008)$ & $0.590(0.015)$ & \\
\hline Nitrogen & 2 months & X052 & $0.236(0.006)$ & $0.472(0.012)$ & \\
\hline Air & 2 months & $\mathrm{X} 006$ & $1.574(0.040)$ & $3.148(0.080)$ & \\
\hline Air & 2 months & $\mathrm{X} 025$ & $1.535(0.039)$ & $3.030(0.077)$ & \\
\hline Air & 2 months & X026 & $1.535(0.039)$ & $3.030(0.077)$ & \\
\hline Nitrogen & 6 months & $\mathrm{X011}$ & $1.338(0.034)$ & $0.0078(0.0005)$ & $\begin{array}{l}\text { Few pits } 9.84 \mathrm{mil} \\
(0.25 \mathrm{~mm}) \\
\text { submerged }\end{array}$ \\
\hline Air & 6 months & $\mathrm{X} 053$ & & $2.676(0.068)$ & $\begin{array}{l}\text { More pits } 9.84 \mathrm{mil} \\
(0.25 \mathrm{~mm}) \\
\text { submerged and vapor }\end{array}$ \\
\hline Nitrogen & 18 months & $\mathrm{X} 051$ & $0.039(0.001)$ & $0.079(0.002)$ & Few pits $23.61 \mathrm{mil}$ \\
\hline Nitrogen & 18 months & $\mathrm{X} 055$ & $0.039(0.001)$ & $0.079(0.002)$ & $(0.6 \mathrm{mil})$, submerged \\
\hline & & & & & Much heavier 19.68 \\
\hline Air & 18 months & $\mathrm{X} 062$ & $1.181(0.030)$ & $2.322(0.059)$ & to $23.61 \mathrm{mils}(.0 .5$ to \\
\hline Air & 18 months & $\mathrm{X} 063$ & $1.181(0.030)$ & $2.400(0.061)$ & $0.6 \mathrm{~mm}$ ), submerged \\
\hline
\end{tabular}




\subsection{Abatement of Water Infiltration}

As mentioned under nitrogen-inerting, corrosion can also be mitigated by eliminating the electrolytic bridge. It is a challenging task to perform this procedure with the high-water table in the Tank Farm area; however, efforts are continuing in that direction.

As pointed out previously, water was infiltrating the vaults of the tanks at some of the locations where modifications (e.g., installation of risers and pump pits) were made in 1986 subsequent to the original construction. Therefore, a bentonite/portland cement slurry was injected around the Tank $8 \mathrm{D}-2$ pump pit enclosure (M-8) in October 1996 and has been very successful in reducing water infiltration into the vault. The water level in the pan increased less than $0.04 \mathrm{inch} /$ day (32 gallons/day) despite the wet rainy weather. Prior to placing the seal around the M-8 pit, the pan level was averaging an increase of over one inch/day ( 800 gallons/day).

Once water infiltration of the vaults is brought under control, it will be possible to pursue reduction of the moisture content of the vault atmosphere. Our goal is to lower the vault humidity as low as reasonably achievable.

\subsection{Corrosion Monitoring}

Internal corrosion coupons ( 4 compact-test specimens, 6 plain, 5 U-bend) in Tank 8D- 1 have been exposed for 7 years and will be removed and evaluated in 1997.

External corrosion coupons (222) were installed in the vaults of Tanks 8D-1 and 8D-2 in August 1996 to monitor the external corrosion of the tanks. The coupons are located under the water, in contact with perlite, and in the vapor phase. They will provide valuable corrosion data in the future that will be used to evaluate the effectiveness of the corrective measures taken. 


\subsection{SAFETY MANAGEMENT PHILOSOPHY FOR TANKS 8D-1 AND 8D-2}

It is the policy of the WVDP to analyze facilities and operations to identify all hazards and potential accidents associated with them and to establish design and operational means to mitigate these hazards and potential accidents. The results of the analyses are documented in a Safety Analysis Report (SAR). ${ }^{13}$

It is also WVDP policy that the design and operation of facilities like Tanks $8 \mathrm{D}-1$ and $8 \mathrm{D}-2$ provide defensein-depth for public and worker safety during normal, off-normal, and accident conditions including tank leakage. Implementation of the defense-in-depth philosophy ensures that layers of defense are provided against the release of radiological and hazardous materials so that no one layer by itself is completely relied upon.

\subsection{Safety Analysis of Tanks 8D-1 and 8D-2}

Tanks 8D-1 and 8D-2 were both analyzed in WVNS-SAR-002, "Safety Analysis Report for Low Level Waste Processing and Support Activities." (13) A postulated tank leak due to corrosion was analyzed as part of the Process Hazards Analysis (PHA) and was judged to be of negligible consequence, resulting in a risk factor of zero.

A simulated accident (caused by a hypothetical greater-than-design basis earthquake) involving the collapse of Tank 8D-2 and the vault roofs resulting in the complete exposure of the tank contents to the atmosphere, was also analyzed. Results indicated that the dose to the maximally exposed off-site individual was well below the DOE radiological dose acceptance criteria for natural phenomena events.

\subsection{Defense-in-depth Layers for 8D-1 and 8D-2}

The primary layers of defense for Tanks $8 \mathrm{D}-1$ and $8 \mathrm{D}-2$ are:

-- Carbon Steel Pan - The pan has a capacity of about 30,000 gallons and is designed to act as an interim collection vessel or barrier for small leaks. Each pan is provided with liquid level detectors that are designed to actuate an alarm if leakage into the pan occurs. The liquid accumulated in the pan is capable of being sampled and analyzed for the presence of radioactivity. The pan contents are also capable of being pumped back into the tank or to a low-level waste treatment facility.

-- $\quad$ Reinforced Concrete Vault - Each tank is completely enclosed by a reinforced concrete vault that provides secondary containment in the event of a leak. The vault is also equipped with liquid level detection instrumentation and is capable of being pumped out.

-- $\quad$ Silty Till Clay Backfill - The vaults containing. Tanks 8D-1 and 8D-2 are located underground within the silty till clay that is characteristic of the West Valley site. This material, if kept saturated with water, has an extremely low water transmission rate. After the vaults were constructed, the excavation cavities were backfilled and covered with silty till clay.

-- Water Injection Wells - In addition to supplying the water necessary to saturate the silty till, these wells maintain a positive hydraulic head external to the vaults so that leakage would be into the vault if a crack were to occur.

-- Leak Detection Wells - Several standpipes penetrate into the pea gravel located under the vaults for detection of leaks from the tank/vault. 
Waste Tank Farm Groundwater Monitoring Wells - As part of the Site Groundwater Monitoring Program, several wells have been installed in the vicinity of the Waste Tank Farm and are sampled periodically and analyzed for radioactive and hazardous contaminants.

-- $\quad$ Ability to Transfer 8D-1 and 8D-2 Tank Contents - Pumps and piping are provided to transfer the contents of either tank from one to the other in the unlikely event of a tank leak. Transfer paths to tankage located in other waste treatment facilities on site could also be used should it become necessary.

Based on the above discussion, it can be seen that the defense-in-depth safety philosophy has been incorporated into the design and operation of Tanks $8 \mathrm{D}-1$ and $8 \mathrm{D}-2$ and will provide protection against and serve to mitigate the effects of a tank leak if one would occur.

However, the above discussion should not be construed to mean that a leak is acceptable. There are other impacts to consider besides facility safety; e.g., worker exposure during cleanup, cost and schedule impacts to the current Vitrification Project mission, cleanup costs, environmental considerations, impact on the cost of the proposed site closure options, and last, but not least, public perception and reaction. It should also be noted that the $8 \mathrm{D}-2$ pan is known to be defective since construction and the $8 \mathrm{D}-1$ and $8 \mathrm{D}-2$ vaults have been shown to provide less than $100 \%$ containment. For these reasons, our goal should continue to be the prevention of a tank leak through the vigilant monitoring and control of tank corrosion. Of course, cost-benefit analyses should be performed to justify the implementation of any proposed corrective measures. 


\subsection{CONCLUSIONS AND RECOMMENDATIONS}

The analysis of Handbook, experimental, and actual tank sample corrosion data suggests that every available control method should be applied to reduce corrosion and prolong the life of the carbon steel tanks to allow the safe completion of the vitrification process, as well as to accomplish decontamination and closure of the tanks.

To meet this challenge, active corrosion protection and control programs have been implemented for the aging HLW carbon steel tanks at the WVDP. External corrosion is currently being minimized through the use of a nitrogen-inerting system for both carbon steel tanks (8D-1 and 8D-2). A laboratory simulation test showed the effectiveness of using nitrogen to mitigate general corrosion and, to a lesser extent, pitting corrosion.

Abatement of water infiltration into the $8 \mathrm{D}-2$ vault has been dramatically reduced by backfilling the M- 8 riser/pump pit with a bentonite/portland cement slurry. The feasibility of further reducing the moisture content of the vault atmosphere is currently being evaluated.

Given the state of the HLW tanks, the highest priority has been given to the continued removal and vitrification of the HLW to eliminate the hazards associated with their contents. Approximately ten percent of the HLW has been removed and vitrified to date.

Adequate defense-in-depth mechanisms are provided in the design of the HLW tanks to ensure public and worker safety during normal, off-normal, and accident conditions. 


\section{REFERENCES}

1. ASTM, Standard Specification for Light Weight Aggregates for Insulating Concrete, 1964 Book of ANSI/ASTM Standards, pp. 238-244, August 31, 1964.

2. Chesterman, C. W., Industrial Minerals and Rocks, Edited by S. J. Lefond, Th Edition, pp. 927-934, 1975.

3. ASTM, Standard Specification for Carbon-Silicon Steel Plates of Intermediate Tensile Runge for Fusion Welded Boilers and Other Pressure Vessels, 1964 Book of ASTM Standards, p. 175, August $31,1964$.

4. Mackey, D. B. and R. E. Westerman, Private Communication - External Corrosion of Tanks 8D-1 and 8D-2, Pacific Northwest National Laboratory, Richland, WAS, November 22, 1993.

5. American Water Works Association, Internal Corrosion of Water Distribution Systems, Denver, CO, 1985.

6. Chang, J. Y., Ph. D. and D. C. Meess, Private Communication, WVDP The 3rd Annual Corrosion Control and Monitoring Meeting, at West Valley, September 10-11, 1996.

7. Butler, G., M.A., Ph. D., and H. C. K. Ison, A. I. M., Corrosion and Its Prevention in Waters, Figure 1, Reinhold Publishing Company, New York, NY, 1966.

8. Uhlig, H. H., Ph. D., Corrosion Handbook, Pitting and the Effect of Mill Scale, p. 380, p. 502, 1948.

9. Shreir, L. L., Ph. D., Jarman, R. A., Ph. D., G. T. Burstein, Ph. D., Corrosion, Vol. I Metal/Environment Reactions, p. 3:20, 1976.

10. Shukla, R. K., Perkins, A. J., Bourgeois, P. M., Jaromin, R. J., Secen, W. G., and Stroud, D. J., Corrosion Monitoring of High-Level Waste Storage Tank 8D-2 at the West Valley Demonstration Project, NACE/94, February 27 - March 4, 1994.

11. Kunig, R. H., and Jacko, R. J., Second Examination of WVNS Tank 8D-1 Corrosion Specimens after Five Years Exposure, STC 95-9TE4-TFIVE-R1, April 24, 1995.

12. Elmore, M. R. and R. E. Westerman, Private Communication, Nitrogen Inerting, Pacific Northwest National Laboratory, Richland, WAS, 1966.

13. West Valley Demonstration Project, Safety Analysis Report for Low-Level Waste Processing and Support Activities, January 16, 1996.

14. Kirby, G. N., Ph. D., Stop Corrosion of Carbon and Low-alloy Steels, Chemical Engineering Progress, pp 29-38, June 1995. 